\title{
A "Syncretism of Piety": Imagining Global Protestantism in Early Eighteenth-Century Boston, Tranquebar, and Halle
}

\author{
Jan Stievermann \\ Department of History, Heidelberg University, Heidelberg, Baden-Württemberg, Germany \\ Corresponding author. jstievermann@hca.uni-heidelberg.de
}

\begin{abstract}
This essay reexamines the network centered on the Boston Congregational minister and theologian Cotton Mather, the great Pietist theologian August Hermann Francke, several of the latter's associates in Halle and London, and Halle-sponsored Lutheran missionaries in the Danish colony of Tranquebar. It pursues the question what this network (which existed from circa 1710 into the 1730s) reveals about how the idea of a "Protestant religion" evolved as a theological construct and how "Protestantism" as a category of religious identity came to have meaning and resonance across denominational and linguistic divides. Through the Boston-Halle-Tranquebar exchange, the essay argues, "awakened souls" from Anglo-American Reformed and German Lutheran churches converged toward a conservative but dogmatically minimalistic understanding of the Christian religion that combined an intensely Christocentric, biblicist, and experiential piety with an activist-missionary and eschatological orientation-a package which was now equated with being truly "Protestant" or "protestantisch," respectively. This reflects how the historical development of "Protestantism" intersected with larger philosophical and theological debates about "religion" and the different "religions" of humanity that involved Enlightenment thinkers as much as awakened Christians. The distinct version of "the Protestant religion" that first developed among the correspondents of this network would continue to evolve through the transatlantic awakenings of the eighteenth century and remain influential into the nineteenth century.
\end{abstract}

Between 1716 and his death, the Boston Congregational minister and theologian Cotton Mather (1663-1728) maintained an intermittent but remarkable correspondence halfway across the globe, exchanging letters, literature, and even donations with Hallesponsored Lutheran missionaries in the Danish colony of Tranquebar (Tharangambadi), southern India. The Boston-Tranquebar correspondence was part of a larger epistolary network between Mather and, at least tangentially, other early New England ministers

The author would like to thank Mark Peterson, Michael Bergunder, and the two anonymous readers for their insightful feedback. Thanks also to Everett Messamore and Layla Koch who helped with revising the essay for publication.

(C) The Author(s), 2021. Published by Cambridge University Press on behalf of American Society of Church History. This is an Open Access article, distributed under the terms of the Creative Commons Attribution licence (http://creativecommons. org/licenses/by/4.0/), which permits unrestricted re-use, distribution, and reproduction in any medium, provided the original work is properly cited. 
on the one side and the great Pietist theologian August Hermann Francke (1663-1727) and several associates in Halle and London on the other. This network emerged around 1710 and flourished until the passing of Francke and Mather, after which it declined despite the effort of their sons and colleagues to keep it alive into the mid-1730s. ${ }^{1}$

In quantitative terms, these exchanges may not appear that noteworthy, ${ }^{2}$ even as more material has surfaced from the Halle archives in the past few years, some of which will be reconstructed here for the first time. Yet the conversation between Boston, Halle, and Tranquebar is significant from a number of viewpoints that still await fuller consideration. ${ }^{3}$ It initiated a special relationship between Prussian Pietism and early evangelicals from New England that far outlasted the demise of the Boston-Halle-Tranquebar network. ${ }^{4}$ More importantly, the correspondence between Mather and his Pietist interlocutors provides a fascinating window into the beginnings of Protestantism as a "world religion." ${ }^{5}$ Recently, Daniel Jeyaraj and Edward E. Andrews made the convincing argument that, although as an actual missionary site Tranquebar might have accomplished comparatively little, it was outstanding for the fact that it was sustained by joint efforts of European and British actors, if only for a relatively short period of time. Its true significance, however, was how it served as a discursive knot "that linked Indian, Danish, German, British, and American Protestants together through monetary, epistolary, and textual exchanges" and provided them with a common point of reference in the process of defining "an expansive imagined community

\footnotetext{
${ }^{1}$ See Kuno Francke, "Cotton Mather and August Hermann Francke," Harvard Studies and Notes in Philosophy and Literature 5 (1896): 57-67; Kuno Francke, "Further Documents Concerning Cotton Mather and August Hermann Francke," Americana Germanica 1 (1897): 31-66; Kuno Francke, "The Beginning of Cotton Mather's Correspondence with August Hermann Francke," Philological Quarterly 5 (1926): 193-195; and the update by Oliver Scheiding, "The World as Parish: Cotton Mather, August Hermann Francke, and Transatlantic Religious Networks," in Cotton Mather and Biblia AmericanaAmerica's First Bible Commentary: Essays in Reappraisal, ed. Reiner Smolinski and Jan Stievermann (Tübingen: Mohr Siebeck, 2010), 131-167.

${ }^{2}$ Based on incomplete knowledge of the sources, this is the point made by Wolfgang Splitter, "The Fact and Fiction of Cotton Mather's Correspondence with German Pietist August Hermann Francke," New England Quarterly 83, no. 1 (March 2010): 102-22.

${ }^{3}$ With limited archival access, Ernst Benz wrote two pioneering studies: Ernst Benz, "Pietist and Puritan Sources of Early Protestant World Missions (Cotton Mather and A. H. Francke)," Church History 20, no. 2 (June 1951): 28-55; and Ernst Benz, "Ecumenical Relations between Boston Puritanism and German Pietism (Cotton Mather and August Hermann Francke)," Harvard Theological Review 54, no. 3 (July 1961): 159-193. See also James A. De Jong, As the Waters Cover the Sea: Millennial Expectations in the Rise of Anglo-American Missions, 1640-1810 (Kampen: J. H. Kok, 1970), 99-105; Charles L. Chaney, The Birth of Missions in America (South Pasadena, Ca.: William Carey Library, 1976), 49-57; William R. Hutchinson, Errand to the World: American Protestant Thought and Foreign Missions (Chicago: University Chicago Press, 1987), 38-40; and Mukhtar Ali Isani, "Cotton Mather and the Orient," New England Quarterly 43, no. 1 (March 1970): 46-58.

${ }^{4}$ See Jan Stievermann, "Halle Pietism and its Perception of the American Great Awakening: The Example of Johann Adam Steinmetz," in The Transatlantic World of Heinrich Melchior Mühlenberg in the Eighteenth Century, ed. Hermann Wellenreuther, Thomas Müller-Bahlke, and A. Gregg Roeber (Halle: Verlag der Franckeschen Stiftungen, 2013), 213-246; and Frank Lambert, "Pietas Hallensis and the American Great Awakening," in The Transatlantic World of Heinrich Melchior Mühlenberg in the Eighteenth Century, ed. Hermann Wellenreuther, Thomas Müller-Bahlke, and A. Gregg Roeber (Halle: Verlag der Franckeschen Stiftungen, 2013), 199-212.

${ }^{5}$ I borrow this phrase from Simon Ditchfield's forthcoming study Papacy and People: The Making of Roman Catholicism as a World Religion, 1500-1700.
} 
that scholars have called the "Protestant International."'6 This point is well taken but begs a deeper question: what does the Boston-Tranquebar-Halle conversation tell us about the historical evolution of "Protestantism" as a theological construct and category of religious identity that came to have meaning and resonance across denominational and linguistic divides?

The Boston-Tranquebar-Halle connection was one important conduit through which the category of Protestantism crossed over from Britain into the world of Continental Pietism, resulting in new interpretations. This is notable because the prevalent opinion (especially in German historiography) still holds that the adoption of Protestantism as a transconfessional and transnational identity happened mostly at the hands of Enlightenment theologians in the second half of the eighteenth century. ${ }^{7}$ As this essay argues, pietistic, revivalist-oriented clergymen created their own versions of pan-Protestantism and started to do so even earlier. Mather, Francke, and Francke's associates, it should be emphasized, were not the only ones. Around the turn of the eighteenth century, some leaders of the Huguenot diaspora, for example, used their farflung contacts to promote a joint cause of Protestantism in the face of popish aggression. Also significant is the Philadelphian Society of Jane Leade and John Pordage, whose eschatological vision of unity was widely appropriated among radical Pietist groups as well as the renewed Unitas Fratrum. By the mid-eighteenth century, the Moravians-guided by Zinzendorf's theology of tropes-would promote a union movement attempting not only to associate the pious among different evangelical confessions but also reconcile Western and Eastern Christianity. ${ }^{8}$ The Boston-Halle-Tranquebar connection partly preceded, partly overlapped with these other discourses while diverging from each in notable regards. No claims are made here about their relative weight or about genealogies of influence among them.

The version of Protestantism negotiated through the Boston-Tranquebar-Halle channels is remarkable for its combination of revivalistic and missionary fervor with a more conservative commitment to confessional orthodoxies and established church polities. Even more remarkable is how Mather and his Pietist correspondents frequently focused their exchange on the essentials of the Christian religion. This reveals how, through international reform projects and collaborations such as Tranquebar, the inherited British understanding of Protestantism was changing. While in English usage, Protestantism had previously served mostly as an ecclesial umbrella term for different evangelical churches, it now became defined as the one true "religion" among other,

\footnotetext{
${ }^{6}$ Edward E. Andrews, "Tranquebar: Charting the Protestant International in the British Atlantic and Beyond," The William and Mary Quarterly, 3rd series, 74, no. 1 (January 2017): 3-34, at 34 and 3. Daniel Jeyaraj makes a similar point in "Cotton Mather's India Americana (1721): Transcontinental Communications between Tranquebar in India and Boston in North America," in Etappen der Globalisierung in christentumsgeschichtlicher Perspektive/Phases of Globalization in the History of Christianity, ed. Klaus Koschorke (Wiesbaden: Harrasowitz, 2012), 195-215; and Daniel Jeyaraj, "Mission Reports from South India and Their Impact on the Western Mind: The Tranquebar Mission of the Eighteenth Century," in Converting Colonialism: Visions and Realities in Mission History, 17061914, ed. Dana L. Robert (Grand Rapids, Mich.: Eerdmans, 2008), 21-42. See also Brijraj Singh, “One Soul, tho' not one Soyl'? International Protestantism and Ecumenism at the Beginning of the Eighteenth Century," Studies in Eighteenth-Century Culture 31 (2002): 61-84.

${ }^{7}$ On this historiography, see Friedrich Wilhelm Graf, Der Protestantismus: Geschichte und Gegenwart (München: Beck, 2006), 1-19.

${ }^{8}$ On the Moravian efforts, see A. G. Roeber, "The Waters of Rebirth: The Eighteenth Century and Transoceanic Protestant Christianity," Church History 79, no. 1 (March 2010): 40-76.
} 
corrupted, "religions." As such, the Protestant religion provided an identity category that could be shared by all true believers across the churches of the Reformation as well as more recent dissenting groups. At the same time, pan-Protestantism became a utopian project to be realized in history by spreading the kingdom of Christ across the globe. This reflects how the evolution of Protestantism intersected with larger philosophical and theological debates about "religion" and the different "religions" of humanity that involved Enlightenment thinkers as much as awakened Christians.

Politically, these conversations were linked into concrete negotiations over ecclesiastical unions both in Britain and Europe. They took place in a geopolitical situation of intensifying contest between Catholic and Protestant powers over European hegemony and overseas empire. ${ }^{9}$ Mather and other heirs of American Puritanism may have been marginal to these European struggles. Yet their place in the American wilderness, their missions, and their tradition of conversion-oriented piety made them fascinating and attractive conversation partners for Continental Pietists as these expanded their evangelistic efforts to India and beyond. Speaking to each other from the edges of the Christian world in what they called the West and East Indies, these men were uniquely positioned to reimagine Protestantism as a global religion and dream of its eschatological triumph.

\section{The Protestant Discourse around $\mathbf{1 7 0 0}$}

It is now widely recognized that the concept of "religion" as we understand it today is of fairly recent origin. The notion that "religion" was a "sphere of life separate from politics, economics, and science" slowly coalesced in the seventeenth and early eighteenth centuries while continuing to crucially evolve after that. Partially in response to confessional strife, religion was increasingly circumscribed as a realm of inwardly held beliefs and ethical behavior rather than the ritualistic or practical aspects of (Christian) worship. This framework was "projected outward into space" in the context of colonial encounters with non-European cultures and "backward in time," leading to the widespread understanding that "religion" was a universal feature of human history whose essential properties could be identified across different periods and cultures, albeit with Christianity as the implicit norm. ${ }^{10}$

We know far less about the development of "Protestantism" as a related concept and identity category. The few studies on the German-speaking world suggest that the terms Protestanten or protestantisch were hardly ever employed either as positively defined theological concepts or as labels of religious self-identification before the mid-eighteenth

\footnotetext{
${ }^{9}$ Alexander Schunka, "Daniel Ernst Jablonski, Pietism, and Ecclesiastical Union," in Pietism, Revivalism and Modernity, 1650-1850, ed. Fred van Lieburg (Newcastle upon Tyne: Cambridge Scholars Publishing, 2008), 23-41, 23; and Alexander Schunka, "Zwischen Kontingenz und Providenz: Frühe Englandkontakte der Halleschen Pietisten und Protestantische Irenik um 1700,” Pietismus und Neuzeit 34 (2008): 82-114.

${ }^{10}$ Peter Harrison, “Science' and 'Religion': Constructing the Boundaries," The Journal of Religion 86, no. 1 (January 2006): 81-106, at 81 and 101. See also Peter Harrison, 'Religion' and the Religions in the English Enlightenment (Cambridge: Cambridge University Press, 1990); and Brent Nongbri, Before Religion: A History of a Modern Concept (New Haven: Yale University Press, 2013), 7. See also Michael Bergunder, "Religionen," in Enzyklopädie der Neuzeit, ed. Friedrich Jaeger (Stuttgart: J. B. Metzler, 2014), consulted online and accessed on March 26, 2020, https://referenceworks.brillonline.com/browse/enzyklopaedie- derneuzeit; and Michael Bergunder, "What is Religion? The Unexplained Subject Matter of Religious Studies," Method and Theory in the Study of Religion 26 (2014): 246-286.
} 
century. ${ }^{11}$ The abstract noun Protestantismus seems not to have been in use at all before circa 1800. Borne out of the conflicts of the Reformation period, the original meanings of the Latin protestantes as a group category were legal and political, traceable to those princes and free cities that dissented from the resolution of the second Diet of Speyer in 1529 and submitted a legal protestatio against the imperial policy. From then on, the estates supporting the Reformers came to be referred to as protestantes or, in German, either as Protestierende or Protestanten. While sometimes used in a more or less neutral sense, the category was primarily invoked by their Catholic opponents to brand them as willful schismatics. Only rarely did theologians or jurists affiliated with the corpus evangelicorum appropriate the category during the sixteenth and seventeenth centuries, not least because the always fragile religious order of the empire came to rest on the legal recognition of "Lutheran" and then, under the Peace of Westphalia (1648), also "Reformed" or "Calvinist" churches. Moreover, confessional strife between Lutherans and Reformed remained intense.

It was only around the turn of the eighteenth century that new theological and philosophical trends began to challenge these deeply entrenched confessional boundaries and prepare the way for the use of Protestanten or protestantisch as positive terms. Scholars have acknowledged that Pietism played a pioneering role in this shift by de-emphasizing the differences between Lutherans and Reformed and by engaging in ecumenical cooperation with other traditions. ${ }^{12}$ According to Friedrich Wilhelm Graf and others, however, the decisive step in this process was taken by German rationalist theologians, such as Johann Lorenz von Mosheim (1693-1755) and Johann Salomo Semler (1725-1791), who forged a close connection between "the Protestant religion" and reasonableness, individuality, freedom, independent thinking, interiority, and moral virtue-a connection which would dominate the later discourse about "Protestantism" and "Protestant culture" through the Romantic period and beyond. ${ }^{13}$

By contrast, Reformation theologians in England and Scotland (as well as France and the Netherlands) were already talking about "Protestants" or "the Protestant religion" by the middle of the sixteenth century to distinguish themselves from Rome. ${ }^{14}$ Since the Elizabethan period, England was regularly heralded as "the Protestant nation." The abstract noun "Protestantism" was introduced in the seventeenth century and used especially among Puritans in opposition to the "papist religion." The notion of a common "Protestant religion" was actively promoted by irenicist and millenarian circles, notably the one around Samuel Hartlib and John Dury, evinced in the latter's

\footnotetext{
${ }^{11}$ Johannes Wallmann, "Protestantismus," in Religion in Geschichte und Gegenwart, 4th ed., vol. 6 (Tübingen: Mohr Siebeck, 2003), 1729-1733; and Christian Albrecht, Historische Kulturwissenschaft neuzeitlicher Christentumspraxis: Klassische Protestantismustheorien in ihrer Bedeutung für das Selbstverständnis der Praktischen Theologie (Tübingen: Mohr Siebeck, 2000).

${ }^{12}$ Erich Beyreuther, August Hermann Francke und die Anfänge der Ökumenischen Bewegung (Hamburg: Herbert Reich Evang. Verlag, 1957); and Martin Brecht, "Pietismus und Irenik," in Irenik und Antikonfessionalismus im 17. und 18. Jahrhundert, ed. Harm Klueting (Hildesheim: Olms, 2003), 211-223.

${ }^{13}$ See Friedrich Wilhelm Graf and Walter Sparn, "Protestantismus," in Enzyklopädie der Neuzeit, ed. Friedrich Jaeger (2014), accessed March 26, 2020, https://referenceworks.brillonline.com/browse/enzyklo paedie-der-neuzeit; and Gottfried Hornig, "Das Abflauen der konfessionellen Polemik in der protestantischen Aufklärungstheologie des 18. Jahrhunderts," in Irenik und Antikonfessionalismus, ed. Harm Klueting (Hildesheim: Olms, 2003), 177-192.

${ }^{14}$ See, for example, William Barlow, Defense of the Articles of the Protestant Religion (1601); or William Chillingworth, The Religion of Protestants a Safe Way to Salvation (1638).
} 
The Interest of England in the Protestant Cause (1659). ${ }^{15}$ Following the Restoration, more rationalist latitudinarians also took up the cause, such as the Anglican theologian Edwards Stillingfleet, who published A Rational Account of the Grounds of Protestant Religion (1664). Nonetheless, the distinctions between Anglicans, Presbyterians, and other dissenting groups remained of the greatest importance during the Civil War and Restoration.

After the Glorious Revolution, the new religious order established by the Act of Toleration (1689) and the Act of Union (1707) between Anglican England and Presbyterian Scotland cultivated a broad understanding of Protestantism as the religion of a united Britain. A number of studies have argued that this new discourse of pan-Protestantism was not only instrumental for the internal consolidation of Britain but that it also undergirded a new phase of imperial policy based on "a broadly shared culture that united believers from different Protestant churches. . . into a common Anglophone spiritual orientation."16

Recent scholarship highlights the centrality of networks between diverse groups of "awakened Christians" for the emergence of an imperial British pan-Protestantism. ${ }^{17}$ Struggling to define their place in the British Empire, the eighteenth-century heirs of New England Puritanism-and none more than Cotton Mather-were especially eager, as Thomas Kidd has demonstrated, to reinvent themselves as quintessential representatives of this common "Protestant interest," which occasionally involved a symbolic identification with "an international Protestant community" of true Christians locked in battle with "Popery." 18 Overall, however, Anglo-American scholarship sees these connections as marginal.

Mather's correspondence with Halle and its Indian missionaries shows that the English- and German-speaking discourses of Protestantism in the early eighteenth century were, in fact, more closely entangled than has been acknowledged. Moreover, the correspondence illustrates that the intersecting discourses on Protestantism and religion were by no means the exclusive domains of rationalists. Even before the generation of the Great Awakening, Pietist and evangelical theologians conceptualized and propagated their own versions of the "Protestant religion."19

\section{The Boston-Halle-Tranquebar Network}

In 1704, the Danish king Frederick IV (1671-1730) decided to establish a Lutheran mission to the Tamil people at the colonial trading post of Tranquebar on the Coromandel Coast. Portugal had been active in this area for some time as well, so

\footnotetext{
${ }^{15}$ Sebastian Barteleit, "Protestantische Einheit und Antikatholizismus: Politisch-religiöse Argumentationsmuster im England der 1650er Jahre," in Irenik und Antikonfessionalismus, ed. Harm Klueting (Hildesheim: Olms, 2003), 71-90.

${ }^{16}$ Carla Gardina Pestana, Protestant Empire: Religion and the Making of the British Atlantic World (Philadelphia: University of Pennsylvania Press, 2009), 6.

${ }^{17}$ Katherine Carté Engel, “Connecting Protestants in Britain's Eighteenth-Century Atlantic Empire," The William and Mary Quarterly, 3rd series, 75, no. 1 (January 2018): 37-70. See also Mark A. Peterson, "Theopolis Americana: The City-State of Boston, the Republic of Letters, and the Protestant International, 1689-1739," in Soundings in Atlantic History: Latent Structures and Intellectual Currents, 1500-1830, ed. Bernard Bailyn and Patricia L. Denault (Cambridge, Mass.: Harvard University Press, 2009), 329-370.

${ }^{18}$ Thomas Kidd, The Protestant Interest: New England after Puritanism (New Haven: Yale University Press, 2004), 2. See also Andrew Thompson, Britain, Hanover and the Protestant Interest: 1688-1756 (Woodbridge: Boydell \& Brewer, 2006). See also Ulrike Gleixner, "Remapping the World: The Vision of a Protestant Empire in the Eighteenth Century," in Migration and Religion, ed. Barbara BeckerCantarino, Chloe, Beihefte zum Daphnis 46 (2012): 77-90.

${ }^{19}$ Gerald R. McDermott, Jonathan Edwards Confronts the Gods (New York: Oxford University Press, 2011).
} 
another aim was to contain the influence of Jesuit missions and make converts among the Catholic mestiços. ${ }^{20}$ Arriving in 1706, the first missionaries, Bartholomäus Ziegenbalg (1682-1719) and Heinrich Plütschau (1676/1677-1752), were recruited from the budding center of Lutheran Pietism, the Francke Foundation at Glaucha near Halle. ${ }^{21}$ They were followed by Johann Ernst Gründler (1677-1720) three years later. Subsequently, the Francke Foundation became a cosponsor of the enterprise by raising funds-providing literature and other needed goods-as well as granting theological oversight, publicizing and promoting the work of the missionaries, and supplying further Halle-trained candidates as the enterprise expanded. In 1719, Benjamin Schultze (1689-1760) and Nikolaus Dal (1690-1747) made their way to India. They were joined by Martin Bosse (1695-1756), Christian Friedrich Pressier (1697-1738), and Christoph Theodosius Walther (1699-1741) in 1724/1725. From about 1710 onward, the recently founded Anglican Society for the Promotion of Christian Knowledge (SPCK) served as another important financial and logistical supporter of the Tranquebar mission. This happened through the collaboration of its secretary Henry Newman (1670-1743) and the Halle Pietists Anton Wilhelm Böhme (16731722) and later Friedrich Michael Ziegenhagen (1694-1776), ${ }^{22}$ both of whom served as court chaplains in London. Böhme served Prince George, Queen Anne's Danish husband, to whom he had been introduced by Pietist diplomat and secretary to the prince Heinrich Wilhelm Ludolf (1655-1712). Ziegenhagen ministered to the new Hanoverian King George I. By Newman's invitation, August Hermann Francke, along with several of his associates and Tranquebar missionaries, became corresponding members of the SPCK and cultivated contacts among English-speaking Protestants. After 1728, the SPCK even developed their own English-Halle mission at Madras.

Although always wary of Anglican encroachments, Cotton Mather, too, had contacts in the SPCK, including Josiah Woodward (1657-1712), ${ }^{23}$ the great promoter of English

\footnotetext{
${ }^{20}$ On the history of Tranquebar, see Robert Eric Frykenberg, Christianity in India: From Beginning to the Present (Oxford: Oxford University Press, 2008), 142-168; Daniel Jeyaraj, "The History of the Lutheran Churches in India during the Eighteenth Century: An Overview," Lutheran Quarterly 17 (2003): 77-97; and Daniel Jeyaraj, Inkulturation in Tranquebar: Der Beitrag der frühen dänisch-halleschen Mission zum Werden einer indisch-einheimischen Kirche, 1706-1730 (Erlangen: Verlag der Evangelisch-Lutherischen Mission, 1996).

${ }^{21}$ Martin Brecht, "Der Hallische Pietismus in der Mitte des 18. Jahrhunderts-seine Ausstrahlung und sein Niedergang," in Geschichte des Pietismus: Der Pietismus im 18. Jahrhundert, ed. Martin Brecht, vol. 2 (Göttingen: Vandenhoeck \& Ruprecht, 1995), 319-357; and Douglas H. Shantz, An Introduction to German Pietism: Protestant Renewal at the Dawn of Modern Europe (Baltimore: Johns Hopkins University Press, 2013), 117-143, and for Tranquebar and other Halle missions, see 237-269.

${ }^{22}$ Daniel O'Connor, "The Church of England and the Mission in India," in Halle and the Beginning of Protestant Christianity in India, ed. Andreas Gross, Y. Vincent Kumaradoss, and Heike Liebau (Halle: Franckesche Stiftungen zu Halle, 2006), 1:129-141; Daniel L. Brunner, Halle Pietists in England: Anthony William Boehm and the Society for Promoting Christian Knowledge (Göttingen: Vandenhoeck \& Ruprecht, 1993); Arno Sames, Anton Wilhelm Böhme (1673-1722): Studien zum Ökumenischen Denken und Handeln eines Halleschen Pietisten (Göttingen: Vandenhoeck \& Ruprecht, 1990); Christina Jetter-Staib, Halle, England und das Reich Gottes weltweit-Friedrich Michael Ziegenhagen (1694-1776): Hallescher Pietist und Londoner Hofprediger (Halle: Verlag der Franckeschen Stiftungen, 2013); and Norman J. Threinen, "Friedrich Ziegenhagen: The London Connection to India and America," in Halle Pietism, Colonial North America, and the Young United States, ed. Hans-Jürgen Grabbe (Stuttgart: Steiner, 2008), 113-135.

${ }^{23}$ For Mather's contact with Woodward, see Josiah Woodward, An Account of the Progress of the Reformation of Manners, in England, Scotland, and Ireland, and other Parts of Europe and America, 14 th ed. (1704), 9.
} 
reform societies, and especially Newman, who also worked as an agent for New Hampshire in London. It was likely Newman, a Massachusetts native, former Harvard classmate, and friend, who put Mather in touch with Böhme sometime before $1710 .^{24}$ Böhme supplied Mather with English translations of Pietist literature, including the Pietas Hallensis (1705), his promotional history of the Francke Foundation, ${ }^{25}$ and the Propagation of the Gospel in the East, a serialized account of the Tranquebar mission, the first installment of which appeared in $1709 .^{26}$ These works stimulated Mather's growing enthusiasm for Halle Pietism and the work of the Foundation. Mather also had a deep interest in mission. In 1698, he had become a commissioner of the New England Company, the oldest Protestant missionary society, established in 1649. For nearly thirty years, Mather worked energetically as commissioner to revive the missions to the Algonquin tribes after the Anglo-Native wars. ${ }^{27}$.

As a representative of the SPCK, Böhme also initiated and mediated the correspondence between Mather, Francke, co-workers in Halle, and the Tranquebar missionaries. Travelling for several months each way, all the letters, tracts, books, and gifts would go through London. While Böhme and Mather conversed in English, all the other letters were composed in Latin, as the American did not know German nor the Halle theologians English. ${ }^{28}$ It is important to emphasize that these letters were not private but had the character of official reports and pronouncements. They were frequently copied, distributed for promotional purposes, and printed.

Mather first mentioned his plan to enter into a correspondence with Halle in a diary entry from 1709. Apparently this plan included the Tranquebar missionaries from the beginning, about whom he must have learned from Newman or Böhme. ${ }^{29}$ In July 1710, Böhme received a letter from Mather, in which he mentioned that he was waiting for

\footnotetext{
${ }^{24}$ On Newman, see Daniel O'Connor, "Secretaries of the Society for Promoting Christian Knowledge (SPCK) 1699-1743," in Halle and Beginning of Protestant Christianity in India, ed. Andreas Gross, Y. Vincent Kumaradoss, and Heike Liebau (Halle: Franckesche Stiftungen zu Halle, 2006), 3:1562-1563.

${ }^{25}$ Anton Wilhelm Böhme's Pietas Hallensis: or a Publick Demonstration of the Foot-Steps of a Divine Being yet in the World was his expanded translation of August Hermann Francke's Segens-volle Fußstapfen des noch lebenden und waltenden liebreichen und getreuen Gottes [. . .] (1701), in which he sought to promote the work of the Foundation in the English-speaking world by linking it to the efforts of the Anglican voluntary societies. Böhme also translated other works of Pietism, including Johann Arndt's famous Of true Christianity four Books (1712-1714).

${ }^{26}$ Anton Wilhelm Böhme, Propagation of the Gospel in the East: Being an Account of the Success of two Danish Missionaries, lately sent to the East-Indies [. . .], Part 1 (1709). The following year, this 100-page account was supplemented by a 50-page "Part 2," and in 1714 a third installment appeared that updated the account by a digest of letters from Ziegenbalg and Plütschau. By 1720, eight versions of the Propagation of the Gospel in the East were in circulation, which were partly updated editions of the first publication, partly later expansion. Halle also published serialized accounts of the Tranquebar mission based on edited letters in the Hallesche Berichte.

${ }^{27}$ On Mather's missionary work, see Sidney Rooy, The Theology of Missions in the Puritan Tradition (Grand Rapids, Mich.: Eerdmans, 1965), 242-284.

${ }^{28}$ For reasons of space, only the English translations of the Latin letters will be cited in the following. Where available, I took the translations from Mather and Böhme. All other translations from Latin and German are mine.

${ }^{29}$ Cotton Mather mentions Tranquebar already in his Bonifacius: An Essay Upon the Good, that is to be Devised and Designed, By Those Who Desire to Answer the Great End of Life [. . .] (Boston: 1710), 175. So far, the most complete reconstruction of the Mather-Halle-Tranquebar relation has been Joseph Gnanaseelam Muthuraj, We Began at Tranquebar; Vol. 1: SPCK, the Danish-Halle Mission and Anglican Episcopacy in India, 1706-1843 (Delhi: ISPCK, 2010), 5-23. However, Muthuraj does not mention a number of the items discussed here.
} 
more news "from our lovely brethren at Malabar," a term referring to the entire southern tip of India as well as to the Tamil people and language. ${ }^{30}$ In response to letters written by Mather to Halle in 1711 and $1712,{ }^{31}$ Francke sent a long Latin account of the Foundation's history and activities to Boston in $1714 .^{32}$ This account was subsequently published in English by Böhme in $1716^{33}$ and in a much abbreviated form by Mather under the title Nuncia bona e terra longinqua: A brief Account of some good and great Things a doing for the Kingdom of God, in the Midst of Europe (1715). Among the many accomplishments of Halle, Francke gave detailed attention to the Tranquebar mission. At the end of this report, he requested more information from Mather on the missionary work to the "West Indian Heathens" begun under John Eliot (about whom he had learned through an account by Increase Mather published at Halle in German in 1696), ${ }^{34}$ which he intended to share with Tranquebar. ${ }^{35}$

In 1715, Cotton Mather sent Halle a lengthy characterization of his theological views and the New England churches, including the thirty native churches associated with the remaining "praying towns" established by Eliot and Jonathan Mayhew. ${ }^{36}$ A copy of a memo from that same year survives in the archives of the Foundation in which Francke explicitly directs Ziegenbalg to take up correspondence with Mather. ${ }^{37}$ The memo highlights the great interest that the Halle Pietists, having no German missionary tradition to draw on, held in other Protestant missions. ${ }^{38}$ For his part, Mather was so impressed by Halle and its Indian mission that he began to speak of his project to promote "the true American Pietism." 39

\footnotetext{
${ }^{30}$ Cotton Mather, Selected Letters of Cotton Mather, ed. Kenneth Silverman (Baton Rouge: Louisiana State University Press, 1971), 93.

${ }^{31} \mathrm{AFSt} / \mathrm{H}$ D 42, 743-744; AFSt/H D 57, 136-139; AFSt/H C 229: 32a. AFSt refers to the "Archiv der Franckeschen Stiftung"; and ALMW to the "Archiv des Evangelisch-Lutherischen Missionswerkes," also at the Francke Foundation.

${ }^{32}$ AFSt/H D 121: 7. Published in Francke, "Further Documents," 32-53.

${ }^{33}$ Anton Wilhelm Böhme published an almost complete translation of Francke's epistolary account as a preface to the third installment of the Pietas Hallensis (London: 1716) under the heading "A Letter of the Author to a Reverend Divine in New England" (1-61). The account here serves as a continuation of the previous report and brings events up to the year 1714 .

${ }^{34}$ Increase Mather, De Successu Evangelii Apud Indos Occidentales, In Novâ Anglia Epistola, which originated in a letter by Mather to the Reformed theologian Johannes Leusden (1624-1699) at Utrecht and was first printed in London in 1688. In 1693, an expanded edition was printed and then published in German by Halle as Ein Brieff von dem glücklichen Fortgang des Evangelii bey den West-Indianern in Neu-Engeland an den berühmten Herrn Johann Leusden (1696). For the context, see Kristina Bross, "From London to Nonantum: Mission Literature in the Transatlantic English World," in Empires of God: Religious Encounters in the Early Modern Atlantic World, ed. Linda Gregerson and Susan Juster (Philadelphia: University of Pennsylvania Press, 2011), 123-142.

${ }^{35}$ Böhme's loose translation above quoted from Pietas Hallensis, part 3, p. 56-57.

${ }^{36} \mathrm{AFSt} / \mathrm{W}$ II/-/23: 2. Several copies of this letter are extant: AFSt/H D 121: 6 and 6a; Stab/F 32/4: 5; and Stab/F 32/4: 1. Stab refers to the "Staatsbibliothek zu Berlin: Handschriftenabteilung, Nachl. A. H. Francke."

${ }^{37}$ The memo is attached to a copy of Mather's letter: AFSt/H D 121: 6a.

${ }^{38}$ See also the letter of Christian Benedict Michaelis to Christian Wendt from February 1715, AFSt/M 1 C 8: 9 .

${ }^{39}$ Reference is made to "American Pietism" in Cotton Mather, The Diary of Cotton Mather, ed. W. C. Ford, Massachusetts Historical Society Collections, 7th ser., vol. 7-8, 2 vols. (Boston: 1911-1912), 2:23. For published works pushing this project, see, for instance, Cotton Mather, Dust and Ashes: An Essay upon Repentance to the Last (1710); Cotton Mather, The Heavenly Conversation: An Essay upon the Methods of Conversing with a Glorious Christ in every Step of our Life (Boston: 1710); or Cotton Mather, Vital Christianity: A Brief Essay on the Life of God, in the Soul of Man (Boston: 1725). On
} 
Although their first letters to Mather are not extant, we know that the pastors at Tranquebar complied with Francke's wish, since they mention having written to Boston in a report to Halle dating from January $1716,{ }^{40}$ and Mather refers to mail received from Ziegenbalg ten weeks prior when writing to Böhme in August $1716^{41}$ Likely preceded by now lost earlier letters, ${ }^{42}$ Mather sent an account to Tranquebar and Halle on December 31, 1717, in which he embraced Ziegenbalg and his associates as fellow laborers for Christ and laid out his theology of mission. ${ }^{43}$ Diary entries from 1718 suggest that he wrote again that year. ${ }^{44}$ In October 1719, the Halle Reports mention that Mather had been overjoyed to receive a letter from Ziegenbalg and written back to Tranquebar in a very "awakened" manner (gar erwecklich geschrieben). ${ }^{45}$ After this, Mather had to wait two years for a reply, during which he seems to have written to India again. ${ }^{46}$ Gründler penned the reply, as Ziegenbalg had died in February 1719 after protracted sickness. The crisis of Ziegenbalg's illness and death was certainly the main reason for the delay, but the missionaries also seem to have been waiting for word from Halle on how to respond to Mather's hopes for an eschatological revival.

Dated December 10, 1719, Gründler's letter described the trials and successes of the Tranquebar missionaries and Halle's congenial approach to mission. ${ }^{47}$ As a token of gratitude for his donation, Mather also received a rare copy of the New Testament printed in Tamil. Mather subsequently published Gründler's complete Latin letter along with his own 1717 letter to Ziegenbalg (both with a parallel English translation) under the heading "Unio Fidelium: Communications between the Western and Eastern INDIA" as part of his India Christiana (1721). This booklet also contains a missionary sermon, further documents concerning the work of the New England Company, and a short treatise on "The Religion, Which ALL Good Men are united in." 48

After Gründler's death in 1720, there was, as far as I can tell, a four-year hiatus in the direct exchange between Mather and the struggling Tranquebar missionaries. In the

Mather's theological affinities with Halle Pietism, see Richard Lovelace, The American Pietism of Cotton Mather: Origins of American Evangelicalism (Grand Rapids, Mich.: Eerdmans, 1979); and Robert Middlekauff, The Mathers: Three Generations of Puritan Intellectuals, 1596-1728 (New York: Oxford University Press, 1971), ch. 17.

${ }^{40}$ Johann Ernst Gründler to Christian Benedict Michaelis, January 27, 1716, AFSt/M 1 C 9: 16.

${ }^{41}$ Mather, Diary, 2:411. Other mentions of his beginning correspondence with Tranquebar from this period can be found in Mather, Diary, 2:348, 474.

${ }^{42}$ The Halle Reports contain an account of the missionary work that Ziegenbalg made for the SPCK in 1715, which already mentions the correspondence with Mather and quotes from his Bonifacius. See the Zehnte Continuation des Berichts derer Königl[ich] Dänischen Missionarien (Halle: 1719), 840-841.

${ }^{43}$ For copies of the letter, see Stab/F 32/4; AFSt/H D 85, 1363-1372; and ALMW/DHM 9/19: 31. An English translation can be found in the SPCK archive at Cambridge University Library ("INDIA FILE, SPCK Correspondence 1720-1723"): SPCK MS DI/Z/8.

${ }^{44}$ In February 1718, Mather mentions that he was again "writing letters to the East Indies, in my Correspondence with the Danish Missionaries at Malabar." Mather, Diary, 2:516-517; see also 544.

${ }^{45}$ This letter is not extant. See the Vierzehnde Continuation des Berichts derer Königl[ich] Dänischen Missionarien (Halle: 1720), 152.

${ }^{46}$ On February 19, 1719, Böhme wrote to Ziegenbalg and forwarded him a letter as well as a donation by Mather, nudging the missionaries to reply to the American minister. See AFSt/H A 185: 8

${ }^{47}$ For a copy of the letter from Gründler to Mather, see SPCK MS D1/Z/8.

${ }^{48}$ Cotton Mather, India Christiana: A Discourse, delivered unto the Commissioners, for the Propagation of the Gospel among the American Indians: Which is accompanied with several instruments relating to the glorious design of propagating our holy religion, in the Eastern as well as the Western, Indies (Boston: 1721), 56-87. 
meantime, the exchange of literature between Boston, London, and Halle intensified. ${ }^{49}$ In a surviving catalogue, "Scriptiones de Cottonis Matheri," Francke's assistant Johann Heinrich Callenberg itemized all the printed works by Mather that Halle had received over the years, listing no less than eighty-three titles. ${ }^{50}$ Inversely, Mather received via London a steady stream of Halle Pietist literature, including works by Arndt, Francke, and Böhme himself.

Meanwhile, Francke had Callenberg prepare a detailed update on the activities of Francke and the Foundation since 1714. Complemented by a catalogue of works printed at Halle, this was sent to Mather in March $1722 .{ }^{51}$ Callenberg later printed these texts as a 150-page booklet. ${ }^{52}$ When the new group of Halle-trained candidates travelled to India via London in 1724, Francke wrote a memo admonishing them to renew the correspondence with Mather. The memo also contained a copy of another long letter from Mather, cosigned by seven other Boston ministers, including Benjamin Colman. ${ }^{53}$ That same year, Francke gave a lecture for his students in which he treated the propagation of the Gospel in India and America as well as his correspondence with Mather, for whom he expressed nothing but admiration. ${ }^{54}$ Bosse, Pressier, and Walther answered Francke's call to action and wrote to Boston in January 1725, expressing their desire to continue where Gründler had left off. ${ }^{55}$ Mather reciprocated at least one last time before his death with a package dated October 8, 1726. The enclosed letter foregrounds their shared emphasis on practical piety in the mission field. ${ }^{56}$

After the death of Cotton Mather and August Hermann Francke, their sons Samuel and Gotthilf August continued the correspondence for a few years and also collaborated on a Latin biography of the elder Francke. ${ }^{57}$ One surviving letter (dated September 1732) to Bosse, Pressier, and Walther shows that Samuel Mather at least initially made an attempt to maintain the Boston-Tranquebar connection. ${ }^{58}$ While it seems that this particular exchange then came to an end in the mid-1730s, the Puritan-Pietist connection continued in different forms, as will be mentioned below.

\section{Constructing a Protestant Religion}

Significantly, Mather began his 1717 letter to Ziegenbalg by praising missionary work as "the most Noble of all that are or ever can be undertaken among the Children of Men."59 Already in his 1715 letter to Francke, Mather had announced with considerable

\footnotetext{
${ }^{49}$ For evidence of further correspondence with the SPCK around 1722, see W. O. B. Allen and E. McClure, Two Hundred Years: The History of the Society for the Propagation for Promoting Christian Knowledge, 1698-1898 (London: SPCK, 1898), 231-233.

${ }^{50} \mathrm{AFSt} / \mathrm{H}$ D 121: 5.

${ }^{51}$ AFst, W Tit. II sect. 23, Schr. IaFach F: 3.

${ }^{52}$ Johann Heinrich Callenberg, Narratio Epistolica Ad Cott. Matherum Theologum Anglicanum Ecclesiae Et Academiae Bostoniensis In America Directa (Halle: 1735).

${ }^{53}$ August Hermann Francke's "Promemoria" to the missionaries: ALMW/D 1/1: 50. See also AFSt/M IC 15: 81. The copy of Mather's letter is dated to June 26, 1724: ALMW/D 9/19: 32. See also Stab/F 32/4:

4. The original might have been composed earlier.

${ }^{54}$ August Hermann Francke, Lectiones Paraeneticae, delivered 1723-1724. Stück 42, S. 1477ff. AFSt/H N 10.

${ }^{55}$ AFSt/H A 180: 77. See also AFSt/M 1C 16: 25.

${ }^{56} \mathrm{ALMW} / \mathrm{D}$ 9/19: 33 . The original is badly damaged, but there is a copy.

${ }^{57} \mathrm{AFSt} / \mathrm{M} 1 \mathrm{~B}$ 5: 4; AFSt/M 2 H 3: 2; AFSt/M 2 H 3: 1; AFSt/H D 121: 6c; and Samuel Mather, Vita B. Augusti Hermanni Franckii (Boston: 1733).

${ }^{58}$ ALMW/DHM 9/19: 30.

${ }^{59}$ Mather, India Christiana, 62.
} 
pride that the New England Puritans had been the first to truly take up that most noble work in North America by spreading the unadulterated Gospel. While in other writings Mather did not shy away from talking about the decline of missions in New England and was, in fact, using comparisons with projects in the "East Indies" to shame his home audience into action, the letter to Gründler strategically omits this crisis and its causes.

Mather and his Pietist correspondents shared the conviction that the Christian religion in its pure Protestant form was a missionary faith. This conviction stood against the opinion of many representatives of Lutheran and Reformed Orthodoxy who believed that this call had been fulfilled at the end of the apostolic age. Both sides shared a deep frustration and anxiety over how little-virtually nothing-the "Churches of the Reformation" had done on this front "while at the same time," as Mather bitterly noted, "the Church of Rome, strives with an Unwearied and Extravagant Labour, to Propagate the Idolatry and Superstition of Antichrist, and advance the Empire of Satan." ${ }^{60}$ Here, Mather would have primarily been thinking of the great Franciscan and Jesuits missions in New Spain and New France, with the latter's influence reaching into the borderlands of New England. ${ }^{61}$

In his 1719 reply, Gründler confirmed Mather's assessment with a view to India. Ziegenbalg, Gründler, and their associates sensed an overwhelming opposition both from the natives, whose minds and hearts had been so enthralled by Satan, as Gründler claimed, to make them disposed against the Gospel truth, and from their Catholic competitors, who were much more successful. Among other things, they allowed the natives to graft "Paganism" onto their "Popery." 62 If Gründler and Mather perceived a worldwide contest with Catholicism, this, of course, had also to do with the geopolitical situation after the War of the Spanish Succession. In his treatise Menachem: A Very Brief Essay of Tokens for Good (1716), penned right around the same time as the letter to India, Mather addressed this situation in dramatic words. "The prevailing of Popery has been Formidable," he wrote, and, "the Protestant Interest, has been reduced so Low, that it has not at this Day much more than Half of that Extent of People and Countreys, which it had acquired in Sixty Years, after the Appearance of the First Reformers." ${ }^{\prime 3}$

It bears emphasis that Mather here uses the term "Protestant" in a very inclusive sense. While this reflects the general shift in use of the English term after the Glorious Revolution, Mather stretches the languages of pan-Protestantism so far as to comprise not only Anglicanism and all the different churches of the Reformed family (including Baptists) but also Lutherans. In The Stone Cut out of the Mountain, another tract published that year and immediately sent to Halle, Mather makes clear the width of his embrace. All the churches of the Reformation should rally around what he defined as the basic "Maxims of the Everlasting Gospel." 64 As we will see, this notion of an evangelium aeternum was also crucial for his exchange with Halle and Tranquebar. To Mather, there was no time for foolish bickering over theological

\footnotetext{
${ }^{60}$ Mather, India Christiana, 64.

${ }^{61}$ For the historical background, see Dana L. Robert, Christian Mission: How Christianity Became a World Religion (London: Wiley-Blackwell, 2009), ch. 2.

${ }^{62}$ Mather, India Christiana, 85-86.

${ }^{63}$ Cotton Mather, Menachem: A Very Brief Essay of Tokens for Good (Boston: 1716), 31.

${ }^{64}$ Cotton Mather, The Stone Cut out of the Mountain (Boston: 1716), 8.
} 
adiaphora. Ranks had to be closed in the battle against an idolatrous and oppressive "Popish Religion." 65

For New Englanders, the Catholic threat was more than an abstract idea. Starting with the War of the Great Alliance (1689-1697), England and France's fight over ascendancy in North America had played out in a series of frontier conflicts with Nouvelle France, during which French and native raids ripped deeply into the Puritan colonies. The Jesuit missions to the tribes of northern Maine and New York were thus also seen as instruments to create allies in the fight against Britain. New Englanders of Mather's generation grew up with a kind of siege mentality and fear of being swallowed up into France's empire. New England militia men, with the enthusiastic support of ministers such as Mather, partook in the assaults on Port Royal and surrounding Acadia first in 1690 and then again during the War of the Spanish Succession, resulting in the eventual British conquest of that territory in 1710 .

In the Holy Roman Empire, Mather's Pietist friends, too, would have felt that the Lutheran and Reformed estates were on the defensive. Next to the Prussian-ruled duchy of Magdeburg, to which Halle belonged, Frederick August I (1670-1733), the Prince Elector of powerful Saxony, converted to Catholicism in 1697 upon accepting the crown of Poland. This startling event in the heartland of the Reformation raised fears not only about the future of Protestantism in Saxony but in the empire more widely. With Saxony gone, Brandenburg-Prussia, under whose auspices Halle thrived, appeared to many as the new champion of the Protestant cause. Indeed, the Pietists saw themselves as warriors against the advances of Roman "idolatry." After Moritz Wilhelm of Sachsen-Zeitz (1664-1718), a sideline of the electoral House of Wettin, announced his conversion to Catholicism in 1717, Francke became personally involved in saving the duke from the grip of his Jesuit advisor and bringing him back to the Lutheran fold one year later. The episode became something of a cause célèbre and created a flurry of publications from both sides. Significantly, Francke also sent an account of his victory to Mather as part of his extensive 1722 letter, later published as the Narratio epistolica ad Cottonum Matherum. ${ }^{66}$

Since Lutheranism traditionally frowned on any kind of chiliasm, the Halle Pietists were more careful about casting these confrontations with Catholicism in eschatological terms. Among the heirs of Puritanism, however, the global stand-off with the Church of Rome was explicitly interpreted in a millennialist framework as the last raging of the Antichrist before his fall. By the providence of God, the evangelical churches would prevail against all odds. To Mather's mind, the failure of the Stuart uprisings, the capture of Acadia, the Hanoverian succession to the English throne in 1714, and the death of Louis XIV the following year were all providential tokens "for Good unto the Protestant Religion." ${ }^{67}$ Mather also saw his ecumenical efforts as part of this latter-day scenario. "The Reformation of the Church will shortly be revived in greater Purity than ever. The Kingdom of Antichrist shall undergo the Destruction which has been long

\footnotetext{
${ }^{65}$ Mather, The Stone, 9. On "antipopery" and the new pan-Protestantism, see Kidd, The Protestant Interest, ch. 2; and Owen Stanwood "Catholics Protestants, and the Clash of Civilizations in Early America," in The First Prejudice: Religious Tolerance and Intolerance in Early America, ed. Chris Beneke and Christopher S. Grenda (Philadelphia: University of Pennsylvania Press, 2011), 218-240.

${ }^{66}$ Here it forms ch. 18, entitled "De Principe Saxonico, ad ecclesiam evangelicam reducto" (Of the Saxon prince who was brought back to the evangelical church). Cotton Mather immediately used this story for a sermon that was then published as The Princely Convert: a Faithful Relation of the Happy Conversion Lately wrought on His Highness Maurice-William, Prince of Saxony (Boston: 1722).

${ }^{67}$ Mather, Menachem, 34.
} 
hoped for it," Mather asserted in The Stone Cut out of the Mountain. One essential means toward that end was the convergence of the churches of the Reformation around the shared "Maxims of the Everlasting Gospel," which, as Mather wrote with reference to the prophecy of Daniel, "shall be a Stone Cut out of the Mountain, that will smite all the Kingdoms of the Papacy, and break them to pieces, and consume them, and become a Great Mountain, which the whole Earth shall be filled withall."68 At the same time, he, like his Pietist correspondents, thought that the rise of evangelical missions should be viewed as signs of "better times" for the true church and its eventual triumph. ${ }^{69}$

It is against this background that we must understand why Mather and his correspondents expressed a joyful sense of mutual recognition and friendship across hemispheres and denominational boundaries. Just as Francke acknowledged Mather as a like-minded, awakened soul, Gründler spoke of him as one who was invested with all his heart in "the work of GoD for the Conversion \& Salvation of Souls." Mather, in turn, praised the Tranquebar missionaries as engaged in true "Evangelical and indeed Angelical work." Convinced that they were fighting the same enemy and working for the same good in the West and East Indies, Mather and Gründler reflected on how the Gospel should be taught to their respective "Indians."

Mather certainly regarded himself as a representative of orthodox Reformed theology and firmly believed that a Congregational church polity was most scriptural. However, in writing to Tranquebar, he displayed a more ecumenical sentiment as he expressed his ardent desire that Protestant missionaries "would Preach unto the Nations, the Weightier Matters of the Gospel, and the Wheat well cleansed from the Chaff." Significantly, he understood this essential Christianity as a vital and practical piety. "Tis most certain," Mather wrote, "That the Christian Religion is no other than the Doctrine of Living to GoD by CHRIST; and is a Practical Thing rather than a meer Theory; the Intention whereof is, to animate a Real, Solid, Vital PIETY."70

Mather and his correspondents understood the Christian religion as a "Doctrine of Piety" in opposition not only to the false religions of pagan idolatry, Islam, and Judaism but also false versions of Christianity. Their main antagonists included, of course, popery but also dead Lutheran formalism and, for Mather, High Church or Catholic Anglicans. Moreover, they defined their understanding of Protestantism against Rationalism, Deism, and other forms of the radical Enlightenment, which they regarded as idolatry of reason. In no uncertain terms, they affirmed that true Christianity was revealed and taught the opposite of the self-sufficiency of man's reason and moral capacity.

Since the early 1710s, Mather had worked on the project of laying down the "axioms" of the "eternal gospel." He published a first outline in Things to be more thought upon (1713), followed by the more elaborate The Stone Cut out of the Mountain (1716). In these two works, Mather broke down the evangelium aeternum into fourteen maxims ${ }^{71}$ and argued that "the People, who have these Evangelical, and Everlasting Maxims written on their Hearts," constituted the true invisible and universal Church of Christ across

\footnotetext{
${ }^{68}$ Mather, The Stone, 12.

${ }^{69}$ The connection between Protestant ecumenism and eschatology that is reflected in this correspondence is also stressed in Muthuraj, We Began at Tranquebar, 15-20.

${ }^{70}$ Mather, India Christiana, 75, 62, 66.

${ }^{71}$ Mather, The Stone, 11. It seems that the Latin part of The Stone Cut out of the Mountain was directly derived from the letter that Mather had written to Francke the year before, which contains the same fourteen "axiomata" explicated in almost identical words. AFSt/W II/-/23: 2.
} 
times, nations, and confessional divides, "howbeit in Lesser Points they may differ from one another."72

In his 1717 letter to Gründler, Mather went a step further and suggested that the heart of Christianity might consist of as few as three axioms or "Practical Articles, in which all the Children of GOD are United." ${ }^{73}$ For Mather, these three maxims were not abstract dogmatic formula to which rational assent suffices. They must become personal, practical, and experiential truths. Such an experiential appropriation of these truths was only possible through the new birth in Jesus Christ. To the regenerate, the maxims thus became "the Tempers and Actions of that Vital Piety, wherein Men Live unto GOD."74 Hence, in explicating the three maxims, Mather immediately moved from the propositional level of systematic theology to the level of lived religion. ${ }^{75}$

The first is the doctrine of a triune God to be adored as creator and Lord of the world. $^{76}$ While pagans worshipped many gods, and Socinians and Deists falsely construed the Godhead as a unity, true Christianity, Mather believed, was Trinitarian. Belief in the triune God, Mather emphasized, was not a postulate of reason but a personal and heart-felt faith. Most essentially, Mather understood true religion as following the command of God to worship and obey Him, not as answering the dictates of innate moral laws. Next comes the doctrine of Christ, according to which "the CHRIST, who is the Eternal Son of God Incarnate in our Blessed Jesus, is our only Redeemer; who Dying for us, has offered a most Acceptable Sacrifice to the Divine Justice." In Christ we must be "relying by Faith" and place our trust in his grace alone so as to "become Reconciled unto GoD." Herein lies the crucial difference to all forms of idolatrous religion. Man cannot obtain salvation and eternal life by sacrifices or moral action but only "under the Conduct of Him who being received up into the heavens, now Reigns on the Throne of GoD" and who "shall Return unto us to Judge the World." Finally, if having faith means "being filled with the Love of GoD and of CHRIST," this must ultimately bear fruit in our conduct. We "must most Heartily Love our Neighbours; and forever go by that Golden Rule, Whatsoever you would have Men do unto you, do you even the same unto them." Mather equated this "Pure Christianity" with what he viewed as the genuine Protestant religion, defined not in confessional but in strictly biblicist terms.

In Menachem, Mather explicitly spoke of "the Protestant Religion, that is to say, The Christian Religion, rescued from the Abominable Corruptions of Popery; The Religion of Primitive Christianity recovering by Essays of Scriptural Reformation, from the Corruptions which the Antichristian Apostasy Has brought upon it." ${ }^{\text {"78 }}$ At the same time, he interpreted the confessional divisions between the Reformation churches as something "which the Antichristian Spirit of Sectarianism hath contrived

\footnotetext{
${ }^{72} \mathrm{AFSt} / \mathrm{W}$ II/-/23: 2.

${ }^{73}$ Mather, India Christiana, 66.

${ }^{74}$ Mather, India Christiana, 52.

${ }^{75}$ Cotton Mather's reduction to three principal maxims first appeared in print in Malachi: Or, the everlasting Gospel, preached unto the Nations (Boston: 1717), xx. It was then taken up in Cotton Mather, The Tryed Professor (Boston: 1719); Mather, India Christiana, 67-68; Cotton Mather, Three Letters from New-England, relating to the Controversy of the present Time (London: 1721), 9-10; and finally in Cotton Mather, Manuductio ad Ministerium (Boston: 1726), 119-120. On this, see Middlekauff, The Mathers, 305-319.

${ }^{76}$ Mather, India Christiana, 67.

${ }^{77}$ Mather, India Christiana, 68, 63.

${ }^{78}$ Mather, Menachem, 30.
} 
instead of Substantial Christianity." 79 In his letters to Tranquebar, as to Francke, Mather claimed that New England missions were based only on the fundamental articles of primitive Christianity. He also expressed his confidence that the Tranquebar missionaries similarly abstained from exposing the natives to the spirit of sectarianism and based their work on "these Articles of the First Magnitude, wherein True Christianity does Firstly and Chiefly consist."

Remarkably, Gründler showed unbridled enthusiasm for Mather's suggestions for concentrating on the essentials of the Gospel and as an official mouthpiece of Halle, no less. The Francke Foundation was in the loop and expected that these letters would be published like the earlier exchanges between Mather and Francke. "That Method of proceeding which you have been pleased to supply us withal," Gründler wrote, "we have Entertained with the highest Satisfaction." It was the same "that we ourselves make use of here, in treating with Men about the Salvation of their Souls." According to Gründler, the Tranquebar missionaries were, like their New England colleagues, "laying aside those things which are Matters of Mere Opinion, and wholly applying ourselves to This, That CHRIST alone, without any manner of Disguise, may be Propounded and Exhibited." Gründler then listed four essential principles by which the Halle Pietists taught the Christian faith. Similar to Mather's maxims, they blended dogmatic fundamentals with practical piety. The work at their mission, Gründler emphasized, "is Entirely Levell'd at this Mark, that we may admonish and Excite and quicken Men, unto a True Repentance, unto a Living Faith, unto an Undissembling Piety."

These sentiments were also echoed in the official reports published in support of the Tranquebar mission in England. The "Preliminary Discourse Concerning the Character of a Missionary" with which Böhme prefaced the first installment of Propagation of the Gospel in the East (1709) emphasized that evangelization must go beyond conveying "a Notional Divinity" and "a meer change of the Externals of Religion." Rather, Protestant missionaries ought to aim at true conversion of the heart and unification with Christ. Catholic missions were carried out in the spirit of partiality, aiming to spread the Church of Rome rather than the Church of Christ. Protestant missions must take a different approach. "As in other Respects, so particularly in bringing over Souls to a saving knowledge of Religion," Böhme wrote in unison with Mather, "tis highly necessary to distinguish betwixt the Essentials and the Accessory Points of Religion."

The Puritan-Pietist conversation about the essentials of Christianity, of course, stood in a long theological tradition of defining the fundamental articles of the faith. ${ }^{82}$ Closest to the sensibilities of Mather and his Pietist correspondents was a school of seventeenth-century irenicism connected with millenarian and pansophic circles, ${ }^{83}$ notably that around Samuel Hartlib (circa 1600-1662) and John Dury (1596-1680),

\footnotetext{
${ }^{79}$ Mather, Manuductio ad Ministerium, 115.

${ }^{80}$ Mather, India Christiana, 67, 79, 81.

${ }^{81}$ Böhme, Propagation of the Gospel in the East, pt. 1, xv.

${ }^{82}$ Ruth Rouse and Stephen Charles Neill, eds., A History of the Ecumenical Movement: Volume 1, 15171948, 3rd ed. (Le Grand-Saconnex: World Council of Churches Publications, 1993); and Heinz Duchhardt and Günter May, eds., Union-Konversion-Toleranz: Dimensionen der Annäherung zwischen den christlichen Konfessionen im 17. und 18. Jahrhundert (Mainz: von Zabern, 2000).

${ }^{83}$ For other strands of millenarian irenicism, in particular the traditions going back to Johann Heinrich Alsted and Jospeh Mede, see Howard Hotson, "Irenicism in the Confessional Age," in Conciliation and Confession: The Struggle for Unity in the Age of Reform, 1415-1648, ed. Howard P. Louthan and Randall C. Zachman (Notre Dame, Ind.: University of Notre Dame Press, 2004), 228-85; and Jeffrey K. Jue,
} 
which included the famous Moravian theologian and reformer Johann Amos Comenius (1592-1670). The Scottish Reformed divine Dury in particular worked as an ecclesial diplomat and theological writer for religious peace at home and for bringing together the churches of the Reformation on the Continent. He, too, had attempted to define fundamental doctrines that were to be laid down in a common Protestant confession. ${ }^{84}$ Dury was convinced, however, that true unity would come less from councils and declarations than from a common piety rooted in these axioms of faith, and he paired his proposals for fundamental dogmatics with an evolving body of "practical divinity" that laid out a detailed program for holy living in the covenant with Christ. It is worth noting that in his many publications Dury frequently used the terms "Protestant religion" and the "Protestant cause," which included missionary work in the New World. ${ }^{85}$ Mather and Böhme certainly knew Dury's writings as well as those of Comenius and would have been familiar with theologians who advocated their approach, such as Anthony Horneck (1641-1697), Böhme's predecessor at the Savoy Chapel and court chaplain under William and Mary. ${ }^{86}$ Other Halle Pietists, too, were influenced by Hartlib, Dury, and Comenius. They were in close conversation with the grandson of Comenius, the Berlin court preacher Daniel Ernst Jablonski (1660-1741), who attempted to negotiate a confessional union in Brandenburg-Prussia. Although skeptical of Jablonski's political plans, they appreciated his spirit of piety and irenicism. ${ }^{87}$ The tradition of irenicism, together with the pansophic notion of universal reform, advanced by the Hartlib-Dury circle, was thus present at Halle and would have helped to prepare the ground for Gründler's positive response to Mather's proposals.

In many ways, Mather and his correspondents therefore drew on preexisting notions about the possibility for union among the churches of the Reformation. However, in keeping with the intellectual debates of the time, they conceptualized their project more in terms of defining the essence of the Christian religion. They did so in marked contrast to more rationalist theologians, who sought to demonstrate how an Enlightened Christianity was the purest embodiment of universal religious principles to be comprehended by reason. Mather and his Pietist interlocutors instead advocated an understanding of the true Protestant Christian religion that combined fundamental dogmatics and practical divinity with an experimental twist.

Heaven upon Earth: Joseph Mede (1586-1638) and the Legacy of Millennarianism (Dordrecht: Kluwer, 2006).

${ }^{84}$ See, for instance, John Dury, A summarie platform of the heads of a body of practicall divinity which the ministers of the Protestant churches abroad have sued for (1654). On Dury, see Anthony Milton, "The Unchanged Peacemaker'? John Dury and the Politics of Irenicism in England, 1628-1643," in Samuel Hartlib and Universal Reformation: Studies in Intellectual Communication, ed. Mark Greengrass, Michael Leslie, and Timothy Raylor (Cambridge: Cambridge University Press, 1994), 95-117.

${ }^{85}$ See, for instance, John Dury, The plain way of peace and unity in matters of religion [. . .] for the preserving and promoting of the Protestant religion abroad (1660); or John Dury, The interest of England in the Protestant cause (1659).

${ }^{86}$ See Scott Kisker, Foundations for Revival: Anthony Horneck, the Religious Societies and the Construction of an Anglican Pietism (Lanham: Scarecrow Press, 2008).

${ }^{87}$ See Anton Wilhelm Böhme, Universal Love: The Surest Way to Advance the Interest of Religion and Unite the Several Contending Parties about it in a Letter to a Friend (London: 1709), a tract that was subsequently translated into German. In 1710, Böhme also reissued Comenius's work on church union, De Bono Unitatis et Ordinis disciplinaeque ac obedientiae in ecclesia recte constituta vel constituenda ecclesiae Bohemicae ad Anglicanam paraenesis (London: 1660), again followed by a German edition. 
The goal was neither a philosophical abstraction nor a syncretism of creedal formulations but, as Mather put it in his 1710 letter to Böhme, a "syncretism of Piety." There was room enough in this concept for almost all stripes of Protestants as long as they were regenerate souls with their faith grounded in the Bible and centered on Christ. The outer limits of the "principles of the Protestant religion" were thus reached where doctrines were taught, church life organized, or scripture interpreted in ways that kept people from Christ. Mather explained to Böhme that he excluded the more radical forms of Enlightenment theology, specifically Arianism and Deism, from "all my projections for the union of good men in a syncretism of piety" because they "set up another Christ. Their Christ is an idol. They destroy piety and the life of God in the soul." ${ }^{88}$ Radical "enthusiasts" were equally beyond the pale because they undermined the authority of the Bible, claiming new visions and inspirations, and disparaged the scriptural means of grace or even the mediatory role of the historical Jesus Christ over against an "inner Christ."

What Mather and his Halle correspondents converged on can be described as a dogmatically minimalistic but intensely Christocentric, biblicist, conversion-oriented, and eminently practical and activist conceptualization of religion. If Roman Catholicism, the radical Enlightenment, and enthusiasm served as the defining "others" of this pan-Protestant pietism, the new mission fields clearly provided the decisive framework for its formulation. In his letters to Tranquebar and Halle, Mather assured his addressees that the natives were taught the essence of Protestant religion through Eliot's Bible translation and his Algonquin catechism. Mather even included the Algonquin translation of his three maxims in India Christiana. In reporting to Mather about the day-to-day work in Tranquebar, Gründler in turn emphasized that in training native catechists they, too, hewed closely to the basic principles of a scriptural religion. What Gründler neglected to tell his American correspondent was that the Halle missionaries did routinely use Luther's Small Catechism, which Ziegenbalg had translated into Tamil for the instruction of converts.

Even so, the spirit of pan-Protestant irenicism and missionary pragmatism was shared on both sides. After Gründler's death in 1720, Mather's correspondence continued in that same spirit with the new cohort of Halle missionaries. In January 1725, Christian Friedrich Pressier, Martin Bosse, and Christoph Theodosius Walther wrote a Latin note from London on their way to Tranquebar, expressing their gratitude for Mather's continued support and their unreserved admiration for his work. "The Lord's will be done," they closed their update, "be it in heaven (by angels [ab Angelis]), be it on earth (by New Englanders [nova ab Anglis])! . . . Let all nations praise the Lord (in the East and West Indies); let all peoples glorify Him (in the southern as well as the northern regions). ${ }^{\prime 90}$ In October 1726, Mather reciprocated one last time before his death with a letter addressed to Pressier, Bosse, Walter, Benjamin Schultze, and Nikolaus Dal. In it, he once again stressed the commonalities between their endeavors and applauded the Halle Pietists for their "method in religion, not formal but vital, to be preached not with the mouth but the heart, not by word, but by practice, not in dogma but rather in righteous works." 91

\footnotetext{
${ }^{88}$ Mather, Selected Letters, 93.

${ }^{89}$ Mather and his New England colleagues argued these points, for instance, in the anti-Quaker tract: Cotton Mather, James Allen, Joshua Moodey, and Samuel Willard, The Principles of the Protestant religion maintained, and churches of New-England (Boston: 1690).

${ }^{90} \mathrm{AFSt} / \mathrm{M} 1 \mathrm{C}$ 16: 25.

${ }^{91}$ ALMW/DHM 9/19: 33.
} 


\section{IV. "Aboriginal" Religion}

In 1726, the Tranquebar missionaries also received from Halle a brief excerpt from Mather's Magnalia Christi Americana (1702) translated into German. ${ }^{92}$ The excerpt, on the successes of the New England missions under John Eliot and Thomas Mayhew, celebrated the conversion of a native woman named Pammehanuit, who lived on Martha's Vineyard shortly before the arrival of the English and received a vision that there was only one true God. When her child was miraculously preserved, she dedicated him to that God, of whom she soon learned more from Mayhew. Pammehanuit converted to Christianity, and her boy grew up to be a successful preacher named Japhet. ${ }^{93}$ Obviously, Halle intended this to lift the spirits of the men who met with so many obstacles in bringing the Gospel to their "Indians." There is more to the tale of Pammehanuit and Japhet, however. It also encapsulates the belief, shared by Mather and his Pietist correspondents, that God had already revealed himself to the gentiles, even if they had not yet received the fullness of the Gospel. Though grossly distorted into various forms of idolatry, "Indians" in the East and West did have recognizable religious beliefs that made them susceptible to the truth of the Bible.

This points to the above-mentioned context for the Puritan-Pietist attempt to define an unadulterated biblical Protestantism as the essence of the Christian religion: the rise of a comparative approach to "religion" and the encounter with diverse native beliefs and practices that, partly in response to new Enlightenment theories, were conceptualized as other "religions." In many ways, Mather and his correspondents were still beholden to the traditional scheme of a fourfold division used by many Renaissance scholars to organize human religions. ${ }^{94}$ A popular rendition of this scheme was Edward Brerewood's Enquiries Touching the Diversity of Language and Religions (first published in 1614), a work certainly familiar to Mather. According to Brerewood, "There are four sorts or sects of Religions, observed in the sundrie regions of the world: Namely, Idolatry, Mahumetanisme, Judaisme, and Christianity." ${ }^{.95}$ In contrast to the varieties of polytheistic idol worship-whether among the ancient Romans or the "Indians"Judaism, Christianity, and Islam were classified as revealed religions worshipping one God, with the difference that the Qur'an was deemed a false revelation and Mohammed an impostor. The generation of Mather and Francke expanded upon this model and recast it in more genetic and comparative-historical terms. Tracing all religions back to a common Noachite origin, they began to define these within a conceptual framework that combined metaphysical beliefs, ethics, and practices of devotion and worship. There was much overlap here with how rationalistic theologians and Deists were thinking about "religion," yet awakened Protestants were unabashedly Christocentric and Trinitarian in their approach.

\footnotetext{
${ }^{92} \mathrm{AFSt} / \mathrm{H}$ A 180: 78. An extant memo from Georg Friedrich Ziegenhagen in Halle to Friedrich Michael Ziegenhagen in London indicates that this excerpt was sent to Tranquebar along with several letters, books, and supplies: AFSt/H A 180: 74. In February 1722, Francke had asked Böhme in London to purchase the Magnalia for him. AFSt/H A 185: 148.

${ }^{93}$ Cotton Mather, Magnalia Christi Americana: Or, the Ecclesiastical History of New-England, from Its First Planting in the Year 1620, unto the Year of Our Lord, 1698, bk. 6 (London: 1702), 63.

${ }^{94}$ See Bergunder, "Religionen"; David A. Pailin, Attitudes to Other Religions (Manchester: Manchester University Press, 1984); and Frank E. Manuel, The Eighteenth Century Confronts the Gods (Cambridge, Mass.: Harvard University Press, 1959).

${ }^{95}$ Edward Brerewood, Enquiries Touching the Diversity of Language and Religions, vol. 2 (1674), 96.
} 
Mather's Malachi is a striking example of this pietistic ideation of religion as a universal category. Mather's three maxims of faith were more than a minimal consensus on which all good Protestant Christians should agree. They formed the very core of humanity's "aboriginal" religion that could be traced back all the way to the protevangelium received by Adam after the fall. Although much diluted and corrupted, this "aboriginal" religion had been spread across the globe with the descendants of Noah's sons and was in this sense universal. ${ }^{96}$ Buried under countless falsehoods, all historical "religions" were therefore based on belief in a creator god and taught an ethics of reciprocity. However hidden, "every Religion that was in Vogue upon the Face of the Earth" also contained the mysteries of the Trinity and Christ's role as redeemer, revealed to the faithful long before His Incarnation. "There never was any Religion current among Mankind, but what own'd, That GoD the Maker of all things, is to be loved above all; and, That Men ought to treat one another lovingly, and gratefully," Mather asserted. And even "the Homage to our dear SAviour, demanded in our Everlasting Maxims may be Reasonably and very powerfully inferred, from the Concessions, which each of the Three other General Professions have yielded unto us." Therefore, the true and primordial religion had been Trinitarian, and the mysteries of the Trinity had never been wholly lost. This was true for the ancient Judaism of the patriarchs and prophets, which really was "but the First Essay of the Christian Religion," as well as for "pagan religions [that] also contained the 'Dawns of Christianity." "97 The Gospel was the purest expression and gave new force to this universal religion, which had existed since the foundation of the world and persisted through all historical religions. As Mather noted, Jesus was venerated in Islam, although his nature was much misunderstood, and even in the darkest forms of heathen idolatry one could find the vestiges of Noah's Trinitarian prisca theologia.

Operating in different colonial contexts, Puritan and Pietist missions greatly contributed to the expansion of knowledge about these "heathen" or "idolatrous" religions that were not only construed in terms that made them comparable to their own faith but also historically or genetically connected to Judaism and Christianity. The Halle missionaries in Tranquebar left a massive archive in this regard. Most famously, Ziegenbalg penned two voluminous manuscripts on Tamil religion, "Das Malabarische Heidenthum" (1711) and "Genealogie der Malabarischen Götter" (1713), ${ }^{98}$ now seen as pioneering works of ethnography and comparative religious study. ${ }^{99}$ While the New England Puritans and early evangelicals produced nothing that came close to Ziegenbalg's

\footnotetext{
${ }^{96}$ Bartholomäus Ziegenbalg makes the same argument about the primordial religion of Noah in his "The Abomination of Paganism, and the Way for the Pagans to be Saved," in Halle and Beginning of Protestant Christianity in India, ed. Andreas Gross, Y. Vincent Kumaradoss, and Heike Liebau (Halle: Franckesche Stiftungen zu Halle, 2006), 3:1453-1467, where it appears in translation.

${ }^{97}$ Mather, Malachi, 40-41.

${ }^{98}$ Daniel Jeyaraj, ed., Bartholomäus Ziegenbalgs Genealogie der Malabarischen Götter: Edition der Originalfassung von 1713 mit Einleitung, Analyse und Glossar, Neue Hallesche Berichte, vol. 3 (Wiesbaden: Harrassowitz, 2003); Daniel Jeyaraj, ed., A German Exploration of Indian Society: Ziegenbalg's "Malabarian Heathenism"; An Annotated English Translation with an Introduction and Glossary (Chennai: Mylapore Institute for Indigenous Studies, 2006).

${ }^{99}$ Gita Dharampal-Frick, "Malabarisches Heidenthum: Bartholomäus Ziegenbalg über Religion und Gesellschaft der Tamilen,” in Missionsberichte aus Indien im 18. Jahrhundert: Ihre Bedeutung für die europäische Geistesgeschichte und ihr wissenschaftlicher Quellenwert für die Indienkunde, ed. Michael Bergunder and Neue Hallesche Berichte, vol. 1 (Wiesbaden: Harrassowitz, 1999); and Urs App, The Birth of Orientalism (Philadelphia: University of Pennsylvania Press, 2010), 77-132.
} 
accomplishments, they, too, studied Native American religions in a comparative fashion.

An early example is Roger Williams's A Key into the Language of America (1643), particularly its chapter on the beliefs and practices of the Narragansetts. Mather also contributed to this tradition, most influentially perhaps in his missionary biography The Life of the Renowned John Eliot, later incorporated into the Magnalia Christi Americana. Notwithstanding their differences in tone and respect toward the natives, both Williams and Mather essentially constructed the same genealogical narrative: as descendants of Adam and Noah, the indigenous peoples originally partook in a primitive Noachite religion that, over time and under demonic influence, degenerated into polytheism yet still retained a kernel of truth. Significantly, Mather talked about native religions both in terms of intellectual content, such as the belief in divine creation and an immortal soul, and in terms of practice. ${ }^{100}$ Much room is given to the deprecatory description of the rituals and feasts that the natives conducted under the guidance of their powwow as well as to their depraved morals and use of black magic. What elements of true divinity were left in their beliefs were invariably distorted by their idolatry.

This way of thinking about non-European cultures and traditions engendered a new comparative self-reflexivity and rendered the Puritan-Pietist project of pan-Protestantism different from earlier endeavors to overcome inner Christian divisions. In the final analysis, it was an attempt to determine and realize the essential nature of Christianity as the one true religion of humanity at a time when it was confronting "corrupted" forms of religion around the globe. All missionary projects ultimately appeared as attempts at a root-andbranch reformation of native religions, just as Protestantism was born out of the Reformation of medieval Christianity, much corrupted by Catholic idolatry.

In its deepest structural logic, the discourse on "religion" and "religions" shared by Mather and his Pietist correspondents had a strong anti-Catholic bias. For them, the Church of Rome had swerved away from its foundation in scripture and lapsed into a type of idolatry analogous to those of ancient pagans or non-European heathens. Just as they understood primitive Christianity to be at once the restoration and fulfillment of the original religion of the ancient Hebrew patriarchs and the prophets (which had anticipated Christ before being corrupted by legalistic-ceremonial Judaism), Roman Catholicism was a corruption of the pure Christian religion after the usurpation of the church by Antichrist. The Reformation had begun the revitalization of this "primitive" biblical faith that they hoped to bring to fuller realization in their own time and expected to see completed in the purified, post-confessional Protestantism of the millennial church.

\section{Terminological Convergences}

Mather and his colleagues in Old and New England would have identified essential Christianity with the "Protestant religion." The German Pietists clearly shared this basic conviction, but their terminology varied, at least when writing in German or Latin. When writing in English, the Pietists began to adjust to the usage of their Anglophone friends. And, over time, the English usage of "Protestant" was taken over into German. Mather's immediate correspondents in Halle and Tranquebar did not yet make this transition. In their Latin letters to Mather, Gründler, Schultz, and

\footnotetext{
${ }^{100}$ See Mather, Magnalia, 192.
} 
the other missionaries consistently employed the traditional adjective "evanglicus/a," even though its referent was shifting to an expansive understanding of shared Protestant principles. The same is true for Francke and his Halle associates. Similarly, in German texts the Halle Pietists used "evangelisch" and its derivatives.

In his English publications, however, Böhme was already adopting the generalizing terms "Protestant" and "Protestants" to invoke the common identity of true Christians across denominational lines. One example occurs in Böhme's preface to the English edition of Johann Arndt's Of true Christianity, where Arndt is said to be venerable among the truly pious in all "the Protestant Churches." ${ }^{01}$ The German translation, under the new programmatic title "Die Unvollkommenheit der Reformation derer Protestantischen Kirchen" (The Incompleteness of the Reformation of the Protestant Churches), faithfully followed the original. Significantly, the terms "Protestantisch" and "Protestanten" were also occasionally used in publications surrounding the Tranquebar missions. In October 1720, for instance, the Halle Reports included an account written by Ziegenbalg for the SPCK in which he approvingly cited the conclusion of Mather's Bonifacius that summarily addressed the churches of the Reformation as "Protestants" and encouraged them to do more for the propagation of the Gospel and to close the gap on Papists: "O ihr Protestanten! Sollen es euch denn die Papisten zuvor thun?"102

No less interested in and connected to the world of English evangelicals, the next generation of Halle Pietists readily accepted this language and continued to partake in the transoceanic discourse about Protestantism as the one true religion. A particularly striking example by the Halle-affiliated Lutheran superintendent for the duchy of Magdeburg, Johann Adam Steinmetz (1689-1762), must suffice here. In 1738, he undertook a German edition of the most famous revival narrative to come out of the American Great Awakening, Jonathan Edwards's A Faithful Narrative of the Suprising Work of God (1737), which he published under the title Glaubwürdige Nachricht von dem herrlichen Werck Gottes (1738). ${ }^{103}$ In a lengthy introduction, Steinmetz contextualized Edwards's report for his German audience with the help of Mather's Magnalia and called upon his readers to receive the Gospel from abroad in the right spirit. To be sure, Edwards's text revealed some of the persisting ecclesial and dogmatic differences between the Reformed and Lutheran churches, but ultimately the revival work in New England, as Steinmetz emphasized, grew from the same truths common to all the Protestant church. ${ }^{104}$ There was little but praise for Edwards's sound preaching of the new birth, kindred spirituality, and practical piety. The writings of Edwards and

\footnotetext{
${ }^{101}$ Anton Wilhelm Böhme, preface to Of true Christianity four books, by Johann Arndt, trans. by Anton Wilhelm Böhme (1712-1714), xvii; and cited in Anton Wilhelm Böhmens [. . .] Sämtliche Erbauliche Schriften: Anfänglich eintzeln, nunmehr aber zusammen, Theils in Teutscher, theils in Englischer Sprache, aus welcher sie mit Fleiss Ins Teutsche übersetzet worden, ed. and trans. Johann Jacob Rambach, 3 vols. (Altona: 1731-1732), 2:95.

${ }^{102}$ Mather's original is "Protestants, why will you be out-done by popish idolaters!" Mather, Bonifacius, 138. See the Vierzehnde Continuation des Berichts derer Königl[ich] Dänischen Missionarien (Halle: 1720), 841. The same issue also announced that the English nation was very "awakened" (sehr erwecket) and supportive of the "Protestant mission in East India" (die Protestantische Mission in Ost-Indien): Vierzehnde Continuation des Berichts derer Königl[ich] Dänischen Missionarien, 152.

${ }^{103}$ Jan Stievermann, "Faithful Translations: New Discoveries on the German Pietist Reception of Jonathan Edwards," Church History 83, no. 2 (June 2014): 323-365.

${ }^{104}$ Johann Adam Steinmetz, ed., Glaubwürdige Nachricht von dem herrlichen Werck Gottes, Welches sich In Bekehrung vieler hundert Seelen zu Northampton und an anderen Orten in Neu-Engeland geäussert hat (Magdeburg: 1738), preface (no pagination).
} 
his peers left little doubt in Halle circles that the revivals of the First Great Awakening were an authentic and extraordinary outpouring of the Spirit that ought to be taken as a harbinger of the "latter-day rains" ushering in the millennium-the very point discussed by Mather and Gründler, as we will see below. Steinmetz's introduction closes with a prayer that Edwards's narrative may prove fruitful "in particular everywhere in our Germany" and awaken many, "especially in the Protestant church [in der Protestantischen Kirche], from the slumber of sin and carnal security."

This kind of revivalist pan-Protestantism was also promoted in the German-speaking world through the popular Pietist periodicals edited by Steinmetz, the Sammlung Auserlesener Materien zum Bau des Reichs Gottes (Collection of Selected Materials for the Building of God's Kingdom), and its three subsequent incarnations published under slightly different titles from 1736 to 1761 . In these widely read periodicals, German Pietists were treated to news from around the world, including the British colonies, concerning Protestant church reform movements, missions, and revivals, such as those in Tranquebar or New England, indicating advances in the kingdom of God. All these publication enterprises were undergirded by the new global Protestant imaginary.

In sum, Halle, with its wide-ranging international interests and networks, especially in the English-speaking world, significantly contributed to a remarkable transformation. In the context of the Holy Roman Empire, protestantisch and Protestanten had been primarily political and legal categories. In Halle-related devotional writings and magazines of the 1720s, 1730s, and 1740s, they were reimagined as a category of religious identity, anchoring a discourse which articulated not only the commonalities of Lutherans, Calvinists, Anglicans, and various Dissenting churches vis-à-vis Roman Catholicism but also redefined the nature of the Christian religion. Around the same time, the Halle Pietist and renowned jurist Justus Henning Böhmer (1674-1749) adopted this comprehensive understanding of Protestantism for the legal sphere when he authored the first systematic treatment of Protestant ecclesial law in his enormously influential five-volume Ius ecclesiasticum Protestantium (1714-1736).

To be sure, Halle was not solely responsible for this shift in Germany. Enlightenment philosophers and rationalist theologians (many of them in intense conversation with Pietist theologians and their English interlocutors) across the empire engaged in their own-partly overlapping, partly opposed-discourses of Protestantism. But it is no coincidence that even some of the theologians who bridged the growing divides between orthodoxy, Pietism, and rationalism, and who propagated the new concept of Protestantism, also came from Halle. Of particular note is Siegmund Jacob Baumgarten (1706-1757), whose posthumously published Geschichte der Religionspartheyen (History of Religious Parties, 1766) already took the new meaning of the terms protestantisch and Protestanten for granted and sought to explain their rise historically. ${ }^{106}$ With Böhme serving as an important trailblazer, the Halle Pietists were thus important pioneers of pan-Protestantism in the German-speaking realm.

On the Anglophone side, the early eighteenth-century heirs of Puritanism, like Mather and Edwards, helped to denationalize and deconfessionalize the terms "Protestant" and "Protestants." In his early days, Mather would have primarily thought of the British world when reflecting on the state of "the Protestant interest." After the turn of the century, his Pietist brethren in Europe and their activities overseas were constantly on his mind as he prayed for the eschatological revival of religion and the global

\footnotetext{
${ }^{105}$ Steinmetz, Glaubwürdige Nachricht, preface.

${ }^{106}$ On this, see Graf, Der Protestantismus, 14.
} 
advance of Protestant missions. The same was true for the next cohort of New England ministers in the context of the colonial awakening. Men like Edwards, Coleman, or Thomas Prince (1687-1758) had an intense interest in the activities of German Pietists, especially those associated with Halle. Prince, for example, eagerly reported about them in his pioneering evangelical journal Christian History (1743-1745). Hearing about awakenings in Germany and the accomplishments of Halle in the mission field gave them an exhilarating sense of being part of a larger global movement of genuine Protestantism and of living at a significant moment in history in which the kingdom was rapidly progressing. When in the summer of 1739 Edwards preached a series of sermons that would later become A History of the Work of Redemption, he singled out the "remarkable revival of the power and practice of religion in Saxony in Germany" under Francke's leadership as a prime example of the Gospel's progress. He also mentioned the success of the Tranquebar mission in bringing "the Christian Protestant religion." ${ }^{\prime 07}$ Remarkably, Edwards here conflated a unified concept of the Christian religion with an understanding of Protestantism that collapses as nonessential the distinctions between his own Calvinism and the Lutheranism of the Halle Pietists.

The generation of Mather and Francke thus developed an interpretative framework, according to which Puritanism and Lutheran Pietism were seen as different local manifestations of true Protestantism, or what Mather had called the "Universal Religion of PIETY." ${ }^{108}$ In his 1716 letter to Böhme, Mather had made this connection explicit when he talked about "American Puritanism" as being "so much of a Peece with the Frederician Pietism" and referred to "your Arndt, and Franck" as "men of our Universal Religion; who will every way appear more and more in the several Forms of Christianity." 109 In the generation of Edwards and Steinmetz, this sense of belonging to a global community of awakened Protestants was already well established.

It should be emphasized that none of these men thought that true Protestantism had been fully realized except in some individuals and church communities. Religious life in the national churches of Europe appeared to them as mostly lifeless and corrupt. The New England pastors were often no less critical of the church establishment in their own country. In their view, the true Reformation was an unfinished project, one important reason why they were skeptical of Protestant church unions on the political level. Their project of pan-Protestantism was related to, but remained distinct from, all such ecclesiastical schemes as debated among some of the most prominent figures of the time, including Samuel Pufendorf and Leibniz. ${ }^{110}$

\section{Envisioning the Unity of the Church}

One such scheme aimed at the confessional unification between Reformed and Lutherans in Brandenburg-Prussia, first initiated in 1697 at the behest of Elector Frederick III (after 1701, Frederick I, king in Prussia) by the aforementioned court chaplain of Berlin, Daniel Ernst Jablonski. Like his grandfather, he was a member of the Bohemian Unitas Fratrum and an advocate of episcopalianism. Jabolinski, in fact,

\footnotetext{
${ }^{107}$ Jonathan Edwards, The Works of Jonathan Edwards, Vol. 9: History of the Work of Redemption, ed. John F. Wilson (New Haven: Yale University Press, 1989), 436.

${ }^{108}$ Mather, Menachem, 39.

${ }^{109}$ Mather, Diary, 2:411-413.

${ }^{110}$ See Schunka, "Zwischen Kontingenz und Providenz."
} 
proposed the Church of England as a model for this ecclesial union and suggested a liturgy based on a translation of the Anglican Prayer Book. ${ }^{111}$ In 1710, he entered into dialogue with John Sharp, archbishop of York, on the possibility of a larger association between this unified Prussian church and the Church of England, perhaps including other Protestant churches as well. Jablonski also represented his king in negotiations over ecclesiastical unification between various members of the corpus evangelicorum at the Imperial Diet in Regensburg between 1717 and 1726. All these initiatives ultimately failed for political reasons. Yet Jablonski's ideas were widely discussed in England and endorsed by some, not least by the archbishop of Canterbury William Wake (1716-1737), who pushed the project of Protestant union under Anglican auspices. These hopes received new nourishment by the Hanoverian succession, which some saw as a providential occasion for a convergence between Continental Lutheranism and the Church of England. While these plans did not go anywhere either, they must be seen as an important backdrop to the Puritan-Pietist discourse of pan-Protestantism.

Interestingly, none of these political schemes for church unification found any support among the Halle Pietists with whom Mather conversed. ${ }^{112}$ They were equally skeptical of the even more ambitious dreams of reuniting all churches of the Reformation and eventually the whole of Christendom that had been harbored by Heinrich Wilhelm Ludolf. ${ }^{113}$ Although Ludolf was a friend of Francke and Böhme, they put little stock in his grandiose plans of a pan-confessional "Universal Church." Mather was certainly aware of these talks about church unions in Brandenburg-Prussia and Britain as he read Ludolf's writings. However, like his Pietist correspondents, Mather "envisaged a union of hearts, based on regeneration and spiritual renewal, not of diplomatic agreements between ecclesiastical authorities." ${ }^{\prime 14}$ They were not interested in institutional mergers and were even fearful that political unifications might strengthen the power of ecclesial hierarchies within the national churches, endangering the liberties of Dissenters and reformers. "And if at last any Union in matters of Religion should be brought about, without the Spirit of Christ to enliven it," Böhme asked in his Universal Love, "what would it prove but a Political Union at best?"115 Rather than a political Protestant union based on a dogmatic syncretism, they believed in-as Mather put it in his handbook for theology students, Manuductio ad Ministerium (1726) - a "Syncretism of PIETY" that would truly "Unite the People of GoD."116 If only "those that have been all along ingag'd in the reconciling Protestants could lay aside all their unnecessary strifes," waxed Böhme, "then truly some real step might be made towards the uniting of Religions, not in the Sect, but in the Spirit; not in the Form, but in the Power; not in the shadow, but in Truth."117 Thus, new meaning

\footnotetext{
${ }^{111}$ See R. Barry Levis, “The Failure of the Anglican-Prussian Ecumenical Efforts of 1710-1714," Church History 47, no. 4 (December 1978): 381-399.

${ }^{112}$ For Francke's resistance, see Schunka, "Daniel Ernst Jablonski, Pietism, and Ecclesiastical Union," 3031. See also Beyreuther, August Hermann Francke, 286.

${ }^{113}$ Ludolf and other Halle Pietists also dreamed of healing the great schism between East and West. Compare, for instance, Johann Franz Buddeus, Erörterung der Frage ob eine Vereinigung der Römisch-Catholischen und Russischen Kirche zu hoffen sey? (Jena: 1719).

${ }^{114}$ Brunner, Halle Pietists in England, 48.

${ }^{115}$ Böhme, Universal Love, 8.

${ }^{116}$ Mather, Manuductio, 122.

${ }^{117}$ Böhme, Universal Love, 8-9.
} 
was given to the traditional notion of the invisible church as the global community of regenerate Protestants bound together in Christ through the Spirit.

The heirs of New England Puritanism and the Halle Pietists also advocated joint missionary efforts and cross-denominational societies through which Protestants ought to cooperate. They believed that the unity of the Spirit that now animated these collaborations would be fully realized after the destruction of the Antichrist and the onset of the millennial age. In the preface to the third installment of his Propagation of the Gospel in the East (1714), Böhme talked about how in the final age "the Spirit of Division and rancor, of Party and Animosity, of Sect and Envy, will be altogether banished from the Church." ${ }^{\prime 18}$ Mather similarly believed in an eschatological revival and unification of the church. He also agreed with Böhme that the glories of the millennial church were anticipated by the joint activities of earnest Christians for the advancement of Christ's kingdom.

On this side of the millennium, all Protestants should be guaranteed full civil liberties and the freedom to associate and worship, their churches given the right to "Sacred Corporations" and self-government, as Mather argued with a view to the British Empire. For New England, he even proposed a general Protestant establishment in which all Protestant churches would partake in the "Priviledges and Advantages of the Evangelical Church-State" as Protestants practiced pulpit and table fellowship. "And let the Table of the Lord have no Rails about it," Mather wrote, "that shall hinder a Godly Independent, and Presbyterian, and Episcopalian, and Antipedobaptist, and Lutheran, from sitting down together." 119

Ultimately, however, the final age of harmony would not come by human agency. When Mather wrote "that GoD is upon His Way to break down all the false Draughts and Schemes, which the Antichristian Spirit of Sectarianism hath contrived instead of Substantial Christianity," ${ }^{120}$ he meant this quite literally. The Second Coming was not far off. Mather even hoped to see its signs during his lifetime.

In his letter to Ziegenbalg, Mather wrote that he was hopeful, if not certain, that the eschatological "Reformation and Propagation of Religion, will be accompanied, by Granting over again, those Extraordinary Gifts of the Prophetic Spirit, by which the Holy spirit watered the Primitive Church, and at first spread and confirmed the Christian Religion in the World." ${ }^{121}$ While bracketing these thoughts as speculation, Mather envisioned how the latter-day rain of the Spirit prophesied in Joel would come over the earth, bringing the renewal of the charismatic gifts of the early church. Through a massive effusion of the Spirit and with the supernatural help of God's angels, ${ }^{122}$ true Protestantism would spread like wildfire and easily outdo and undo the successes of Catholic missionaries: "But now at last; what if after the Twelve Hundred \& Sixty Years of Antichrist are Expired, there should be heard the Sound of Abundance of Rain!"123 Mather's millennialism and supernaturalism were certainly extreme and caused some discussion among the Halle theologians. ${ }^{124}$ As Lutherans,

\footnotetext{
${ }^{118}$ Anton Wilhelm Böhme, preface to Propagation of the Gospel in the East: Being an Account of the Success of two Danish Missionaries, lately sent to the East-Indies [. . .], Part 3 (1714), v.

${ }^{119}$ Mather, Manuductio, 126-127.

${ }^{120}$ Mather, Manuductio, 115.

${ }^{121}$ Mather, India Christiana, 69.

${ }^{122}$ See also Mather, Malachi, 4.

${ }^{123}$ Mather, India Christiana, 71.

${ }^{124}$ See ALMW/DHM 4/5b: 13.
} 
they were traditionally wary of chiliastic enthusiasm, even as they entertained hopes for "better times" for the church, in Spener's famous phrase. ${ }^{125}$ This throws into relief some of the subtle differences between Mather's Puritan tradition and Lutheran Pietism. More importantly, however, it reveals that in different degrees, an eschatological orientation played a major role for how both sides in this transoceanic conversation thought about the nature and destiny of Protestantism. All were convinced that the final unity and victory of the true Protestant religion would come from a global latter-day renewal of the church, which would also enable the conversion of Jews, Muslims, and heathens around the world. All were convinced that they were called to do their work in anticipation of the coming kingdom.

\section{Conclusion}

Through the Boston-Halle-Tranquebar network, "awakened souls" from Anglo-American Reformed and German Lutheran churches converged toward an understanding of the Christian religion as a practical, experiential, conversionist, and missionary piety with an eschatological orientation. First on the English-speaking side and then, with some delay, on the German-speaking side, this understanding was equated with the transconfessional category "Protestant" or "protestantisch," respectively. While overlapping in other regards, this conceptualization importantly diverged from the understanding of the "Protestant religion" embraced by latitudinarian Anglicans or Deists. Like the later luminaries of German Enlightenment theology, these schools would define reasonableness, interiority, freedom of conscience, and sound morality as "the essence of the newly ideated 'religion" and often held that true religion "had less to do with sincerity of commitment than with whether or not the propositions to which one gave intellectual assent were true."126

Men like Mather or Böhme by no means would have denied that Protestantism was reasonable or conducive to freedom of conscience. But in their minds, these qualities were secondary. For them, the core of Protestantism-and, indeed, of religion per seconsisted in sincerity of faith, expressed by living unto God with heartfelt devotion and an activist praxis pietatis engaged in working for the coming kingdom of God on earth. Dogma did matter to Mather and his Pietist correspondents. Yet there was a willingness to reduce the axioms of faith to a minimal consensus and a strong tendency to downplay the significance of creedal and ritualistic distinctions (even across the traditionally deep Lutheran-Calvinist divide), which in their newly entered mission fields seemed to matter less. Here they conceived of Protestantism as a world religion in the encounter with different heathen religions but also in conscious opposition to "popery" as well as the idolatry of reason they saw in the radical Enlightenment. At a time when diverse schemes were discussed in Europe and Britain to achieve Protestant church unions by political means on a creedal basis, these men envisioned what Mather called a "syncretism of piety" among regenerate individuals connected by the

\footnotetext{
${ }^{125}$ Spener first formulated the "hope for a better state of the church here on earth" in Philipp Jakob Spener, Pia Desideria (1675); and then expanded on it in Philipp Jakob Spener, Behauptung Der Hoffnung künffiger Besserer Zeiten (1693). In both publications, he was very intent on avoiding the faults of a chiliasmus crassus. On this, see Wolfgang Breul, "'Hoffnung besserer Zeiten': Der Wandel der 'Endzeit' im lutherischen Pietismus um 1700," in Frühe Neue Zeiten: Zeitwissen zwischen Reformation und Revolution, ed. Achim Landwehr (Bielefeld: Transcript, 2012), 261-282.

${ }^{126}$ Harrison, "'Science' and 'Religion," 92.
} 
Holy Spirit, who ought to work together from within their existing churches without having to give up their confessional legacy.

This distinct version of "the Protestant religion," developed among the correspondents of this specific network, would remain influential throughout the second half of the eighteenth and into the nineteenth century. The Age of Revolutions and the Napoleonic Wars significantly disrupted transatlantic relations. After 1814, however, Anglo-American evangelicals once again started working closely with their brethren in Europe, especially Germany, where a large-scale Erweckungsbewegung unfolded. One particularly thick strand in this (re-)growing web was between New England and Prussia. Together with their British brethren, New England evangelicals and Pietists within the United Protestant Church of Prussia (centered in Berlin and Halle) were promoting foreign missions in Asia and Africa as well as Bible, tract, and reform societies on an unprecedented scale. These collaborations opened fresh channels of communication through personal encounters, correspondences, and an enormous amount of print publications. ${ }^{127}$ Shared news and translations once again created a distinct public sphere of the pious, from which emerged a renewed sense of common purpose and worldwide community as committed Protestants, who were cultivating the seeds of true religion sown by their eighteenth-century forebears in an age of growing unbelief. A culminating point of these developments would be the founding of the Evangelical Alliance (established in 1846) just before the watershed events of the 1848 revolutions. ${ }^{128}$ With its crucial English-American-German axis, the Alliance was an important heir to the vision of pan-Protestantism first formulated by Mather and his Halle correspondents.

Jan Stievermann is Professor of the History of Christianity in the USA at Heidelberg University, Germany. His work focuses on the cultures of eighteenth- and nineteenth-century American Protestantism, with a special interest in their transatlantic connections. His most recent publication is the Oxford Handbook of Jonathan Edwards (2020), co-edited with Douglas Sweeney, and for the scholarly edition of Cotton Mather's Biblia Americana (1693-1728) he serves as a volume editor (vols. 5 and 10) and executive editor of the whole project.

\footnotetext{
${ }^{127}$ See Wayne Alan Detzler, "British and American Contributors to the 'Erweckung' in Germany, 18151848” (PhD diss., University of Manchester, 1974); and now Andrew Kloes, The German Awakening: Protestant Renewal after the Enlightenment, 1815-1848 (New York: Oxford University Press, 2019).

${ }^{128}$ Philip D. Jordan, The Evangelical Alliance for the United States of America, 1847-1900: Ecumenism, Identity, and the Religion of the Republic (New York: Mellen Press, 1982).
}

Cite this article: Stievermann, Jan. "A "Syncretism of Piety": Imagining Global Protestantism in Early Eighteenth-Century Boston, Tranquebar, and Halle.” Church History 89, no. 4 (December 2020): 829-856. https://doi.org/10.1017/S0009640720001419. 